\title{
Design of very high performance concretes using local aggregates
}

\author{
BELAOURA Mebarek ${ }^{1,}$, , OUDJIT Mohamed Nadjib², BALI Abdelrahim ${ }^{3}$ \\ ${ }^{1}$ Graduate School of Publics Works (ENSTP); 1Rue Sidi Garidi Vieux Kouba Algiers Algeria \\ ${ }^{2}$ Faculty of Civil Engineering, University of Sciences and technology Houari Boumediene (USTHB) Bab Ezzouar Algiers Algeria \\ ${ }^{3}$ Civil Engineering departments, Polytechnic Graduate School (ENSP), El Harrach Algiers Algeria
}

Email address:

belaoura@gmail.com(M. BELAOURA),mohnadoudj@yahoo.fr(M. N. OUDJIT),balianl@yahoo.fr(A. BALI)

To cite this article:

BELAOURA Mebarek, OUDJIT Mohamed Nadjib, BALI Abdelrahim. Design of Very High Performance Concretes Using Local Aggregates. American Journal of Civil Engineering. Vol. 1, No. 2, 2013, pp. 68-73. doi: 10.11648/j.ajce.20130102.14

\begin{abstract}
In recent years, appeared very high performance concretes which are the result of a more and more scientific rationalization. The use of superplasticizers, and more recently of ultrafine particles such as silica fume, has significantly minimized the amount of mixing water in concrete while improving workability. Owing to this water reduction (and thus the w/c ratio), the mechanical strength of such concretes has considerably increased. The compressive strength may exceed 80 $\mathrm{MPa}$. Therefore, their use is very promising from an economic point of view and quality of civil engineering and hydraulics works. The aim of this study is to formulate a VHPC using local materials. The design approach used is the grout method. The obtained results show a clear improvement in the mechanical performance of concrete, resulting in a sufficient compressive strength to allow formwork removal at $24 \mathrm{~h}$, an acceptable tensile strength and shrinkage lower than that obtained in conventional concrete.
\end{abstract}

Keywords: Very High Performance Concrete, Usual Concrete, Local Aggregates, Superplasticizers, Design, Mechanical Behaviour

\section{Introduction}

The manufacture of Very High Performance Concretes (VHPC) is currently in full development in civil engineering, notably in the construction of specific structures such as bridges. The choice of VHPC as material has an impact on the initial cost of construction (superplasticizer, silica fume, cement), but the amount of concrete and reinforcement is reduced [1]. It also has some consequences all along the useful life of the structure [2]. Indeed, this choice significantly reduces activities related to maintenance and repair, and therefore improves durability. In addition, it has a direct impact on the users of the structure, on the society, and therefore, the VHPC is the longest-term economic concrete. This study is part of a project on VHPC design using local materials of Algeria. The physical and mechanical behaviors of these concretes are presented thus.

\section{Materials Used}

\subsection{Cement}

A CEM I 52.5 R artificial Portland cement according to EN 197-1 have been chosen for the investigation.

\subsection{Gravel}

Gravels used in this study are of the same granular class and limestone nature, from two different quarries:

- The first one comes from the region of Biskra (Algeria), having a specific gravity of 2.60 with a coefficient of Los Angeles of $23 \%$.

- The second one is from the region of Constantine (Algeria), having a specific gravity of 2.55 with a coefficient of Los Angeles of $21 \%$.

\subsection{Superplasticizer}

The admixture used is a superplasticizer based on polycarboxylate. 


\subsection{Additions}

The mineral addition incorporated is silica fume, characterized by its density of 2.2 , its particle size $<0.1$ micron and a silica content $>85 \%$.

\section{VHPC Mix Design}

The principle is based on a process of making a concrete with a high compactness according to given specifications. In this sense, two different ways of physical-chemical nature emerged for achieving high performance.

- deflocculating the cement grains, which is obtained by the use of organic products (condensed Formaldehyde and Melamine sulfunate or Naphthalene sulfunate), allows the cement grains in suspension in water to regain their original granularity [3]. This path leads to a significant reduction in the necessary amount of water [4], since high proportion of it is no more, as in ordinary concrete, trapped in flocks of cement grains, and therefore is not useful for workability.

- The extension of the spectrum of the granular mixture: in this method ultrafine (silica fume, limestone filler, etc ...) which are chemically reactive, have been involved to fill the micro-voids, consequently the compactness of the mixture is improved, while still advancing the quality of its rheology in the state fresh is still progressing, whereas, in parallel the amount of water necessary for placing concrete can be further reduced [5]. In terms of achievements, it has been found, by carrying out experiments using local materials, that the application of this mix design procedure without a significant cost increase of concrete allows reaching high performance concretes showing characteristic compressive strength at 28 days ranging from 80 to $110 \mathrm{MPa}$ [6].

\section{VHPC Formulation by the Method of Grout}

This method offers some economic benefits since it requires very small quantities of materials [7]. However, considering the cost of additions and additives, this method allows to get the best price and take account of the rapid loss of workability, hence the interest of a rational method of composition, leading to the control a great number of parameters with a minimum testing.

\subsection{Formulation Process}

Objective: Develop a high performance concrete of a fluid consistency and a specified compressive strength (100 to $110 \mathrm{MPa}$ at 28 days) based on ordinary structural concrete formula for bridges or tunnels and other infrastructures.

\subsubsection{Formulation VHPC "0" Reference}

Add to granular skeleton ( maximum diameter D of 8 to $15 \mathrm{~mm}$ ) of ordinary concrete $500 \mathrm{~kg}$ (for example) of cement [8], and $1.5 \%$ of plasticizer then search the water content, for obtaining a fluid concrete (Marsch cone slump $=20 \mathrm{~cm}$, LCL time below $10 \mathrm{~s}$ ).

\subsubsection{Grout Reference}

Its composition is that of the cement matrix of VHPC reference less water wetting of the aggregates $\left(10 \mathrm{l} / \mathrm{m}^{3}\right.$ concrete). The reference flow time is measured using the Marsch cone, with the adjustment option, with a receptacle, which can be filled from 5 to $15 \mathrm{~s}$ [9]; the time obtained is the reference flow time.

\subsubsection{Mineral Composition of VHP Grout}

The mineral composition of $\mathrm{n}$ grouts is developed, between which the final sought paste for VHPC is chosen, at this stage the following parameters are varied:

- The nature of cement

- The silica fume content (between 5 and $10 \%$ by for cement weight)

\subsubsection{Superplasticizer Content in VHP Grout}

It is necessary to consider the time evolution of the flow as a function of increasing admixture content [10]. The resulting curve will indicate the saturation rate for which the flow time is defined by the next necessary tests.

\subsubsection{Retarding Admixture Content}

The time evolution of the flow of each grout during the use of VHPC has measured (either 1 or $2 \mathrm{~h}$ ). If this time increases significantly, repeat the operation with the addition of retarding admixture, just with a necessary content [11].

\subsubsection{Choice of VHP Grout}

Grout corresponding to the correct couple cementadditive will be that for which the $\mathrm{W} / \mathrm{C}$ ratio obtained will be the lowest. The generalized Feret law will allow then an assessment of the compressive strength, and a selection of the formula of grout considered.

\subsection{Example of Application of the Grout Method}

The aim is to achieve a concrete of $100 \mathrm{MPa}$ of characteristic strength from the following formula:

Table 1: Mix proportions of ordinary concrete in $\mathrm{kg} / \mathrm{m}^{3:}$ Start

\begin{tabular}{lllllll}
\hline $\begin{array}{l}\text { Crushed limestone gravels } \\
8 / 15\end{array}$ & $\begin{array}{l}\text { Sand } \\
\mathbf{0} / 5\end{array}$ & $\begin{array}{l}\text { Cement } \\
\text { CEM I 52.5 R }\end{array}$ & Silica fume & $\begin{array}{l}\text { Superplasticizer } \\
\mathbf{1} / \mathbf{m}^{3}\end{array}$ & water \\
\hline 826 & 713 & 487 & 450 & $/$ & 1 & 182 \\
\hline
\end{tabular}


Table 2: Very high performance concrete " 0 " in $\mathrm{kg} / \mathrm{m}^{3:}$ Phase 01

\begin{tabular}{|c|c|c|c|c|c|c|}
\hline $\begin{array}{l}\text { Gravels } \\
8 / 15\end{array}$ & $3 / 8$ & $\begin{array}{l}\text { Sand } \\
0 / 5\end{array}$ & $\begin{array}{l}\text { Cement } \\
\text { CEM I 52.5 R }\end{array}$ & Silica fume & $\begin{array}{l}\text { Superplasticizer } \\
1 / \mathrm{m}^{3}\end{array}$ & water \\
\hline 765 & 532 & 625 & 550 & I & 7.5 & 145 \\
\hline
\end{tabular}

Abrams cone slump of $20 \mathrm{~cm}$; LCL flow time: $10 \mathrm{~s}$

Table 3: Reference grout in $\mathrm{kg} / \mathrm{m}^{3:}$ Phase 02

\begin{tabular}{lllll}
\hline $\begin{array}{l}\text { Cement } \\
\text { CEM I 52.5 R }\end{array}$ & Silica fume & $\begin{array}{l}\text { Superplasticizer } \\
1 / \mathrm{m}^{3}\end{array}$ & water & Flow time au cone de Marsch (s) \\
\hline 500 & $/$ & 7.5 & 119 & $/$ \\
\hline
\end{tabular}

Phase 03: (VHP grout): choice of binder combination

- $\mathrm{N}^{\circ} 1$ : cement $+5 \%$ silica fume

- $\mathrm{N}^{\circ} 2$ : cement $+10 \%$ silica fume

- $\mathrm{N}^{\circ} 3$ : cement $+15 \%$ silica fume

Phase 04: Determination of saturation admixture content

Marsch cone flow as a function of the percentage of additive by weight of cement [12] is shown in "Fig.1", wherein each point represents an experimental value obtained from a grout whose $\mathrm{W}$ / C ratio has been maintained constant (with plasticizer).

Table 4: Determination of water demand to obtain flow time of 5 s: Phase 05

\begin{tabular}{|c|c|c|c|c|c|c|}
\hline $\begin{array}{l}\text { Cement } \\
\text { CEM I 52.5 R }\end{array}$ & Silica fume & $\begin{array}{l}\text { Superplasticizer } \\
1 / \mathrm{m}^{3}\end{array}$ & $\begin{array}{l}\text { water } \\
\mathrm{kg} / \mathrm{m}^{3}\end{array}$ & Flow time (s) & $\mathbf{w} / \mathbf{c}^{*}$ & $\mathbf{S} / \mathbf{C}^{* *}$ \\
\hline 550 & 27.5 & 8.25 & 139.7 & 5 & 0.254 & 0.05 \\
\hline 528 & 52.8 & 10.03 & 132.52 & 5 & 0.251 & 0.10 \\
\hline 512 & 76.8 & 11.26 & 129.02 & 5 & 0.252 & 0.15 \\
\hline
\end{tabular}

*W/C: Water/Cement ratio

** S/C: Silica fume/ Cement

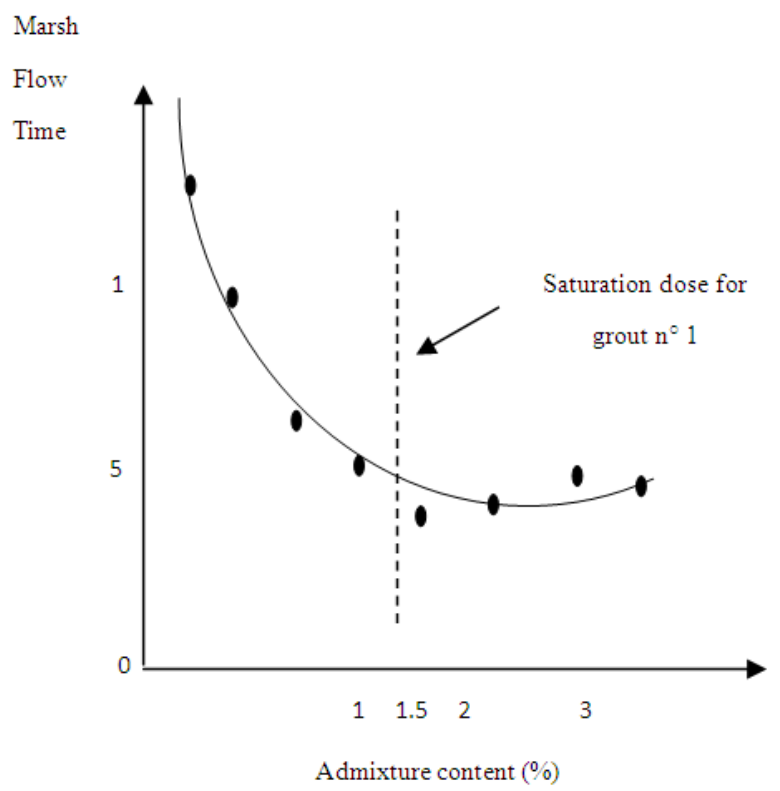

Figure 1. Influence of superplasticizer on flow time.
In Table 5, the formulation of 10 concrete mixtures is reported.

\section{Results and Discussion}

\subsection{Compressive Strength}

The evolution of the compressive strength of cubic specimens $(10 \times 10 \times 10 \mathrm{~cm} 3)$ of 10 VHPC mixtures is shown in "'Fig. 2". It should be noted that from these curves, a significant increase in mechanical strength of elaborated concretes is observed compared to the reference concrete (VHPC 0). The variations in compressive strength are relatively similar for all VHPC formulations. The use of superplasticiser allows a reduction in the water content of the mixture at equal consistency. The $\mathrm{W} / \mathrm{C}$ ratio used is up to 0.25 instead of 0.40 usually used for conventional concrete (a reduction of the water content of more than $40 \%$ is noticed). Superplasticizers opposing the flocculation of the cement grains, so the granular skeleton of conventional 
concretes is embedded in a matrix of increased compactness. The reduced $\mathrm{W} / \mathrm{C}$ ratio means the amount of water is very small compared to the mass of cement and cement grains are very close to each other. All the water will react with the cement, and there will be very little capillary porosity. The permeability of concrete is very low and the mechanical properties of concrete will be very high, which improves durability. The use of ultrafine particles to correct the size grading of the concrete is necessary to achieve better performances of VHPC [13]. The rate of the recorded increase in strength is significant; this results from high cement content.

\subsection{Tensile Strength}

The evolution of the tensile strength of 10 mixtures is shown in "Fig. 3". From the shape of the curves, it can be seen that the tensile strength increases significantly, but with very low values compared to the compressive strength, so the ratio $\mathrm{ft} / \mathrm{fc}$ decreases to $1 / 20$ for the strongest concretes . Furthermore, the development of the tensile strength is faster than the compressive strength.

\subsection{Total Shrinkage}

The evolution of total shrinkage is shown in 'Fig.4". From the shape of the curves, it can be seen that shrinkage deformations develop quasi- linearly for each concrete with a deformation rate superior to that of conventional concrete. The short-term shrinkage is more important: in VHPC containing less water, the cement hydration causes autodessiccation and shrinkage related to this phenomenon more intensely than conventional concrete [14]. At 28 days, VHPC1 (silica fume) has a higher shrinkage of 50 microns / $\mathrm{m}$ compared to VHPC 0 (without silica fume). This behaviour seems coherent with the exothermic pozzolanic reactions of the fines that promote the evaporation of water generating an increase in capillary tension in the open pores [15]. In general, the total shrinkage of VHPC measured on test specimens is less than that recorded on the same specimens of conventional concrete

Table 5: Mix proportions of 10 elaborated VHPC

\begin{tabular}{|c|c|c|c|c|c|c|c|}
\hline VHPC & $\begin{array}{l}\text { W/C } \\
(\mathbf{W} / \mathbf{B}) \\
\end{array}$ & $\begin{array}{l}\text { Water } \\
1 / \mathrm{m}^{3} \\
\end{array}$ & $\begin{array}{l}\text { Cement } \\
\mathrm{Kg} / \mathrm{m}^{3}\end{array}$ & $\begin{array}{l}\text { Gravel } \\
\mathrm{Kg} / \mathrm{m}^{3}\end{array}$ & $\begin{array}{l}\text { Sand } \\
\mathrm{Kg} / \mathrm{m}^{3}\end{array}$ & $\begin{array}{l}\text { Superplasticizer } \\
1 / \mathrm{m}^{3}\end{array}$ & $\begin{array}{l}\text { Silica fume } \\
\mathrm{Kg} / \mathrm{m}^{3}\end{array}$ \\
\hline $\mathbf{0}$ & 0.26 & 145 & 550 & 1297 & 625 & 7.5 & I \\
\hline 1 & 0.251 & 150.6 & 600 & 1065 & 720 & 9.50 & 48 \\
\hline 2 & 0.249 & 147.0 & 590 & 1145 & 680 & 10.12 & 47.2 \\
\hline 3 & 0.254 & 147.32 & 580 & 1278 & 657 & 10.32 & 46.4 \\
\hline 4 & 0.249 & 141.93 & 570 & 1054 & 746 & 11.02 & 45.6 \\
\hline 5 & 0.250 & 140.0 & 560 & 1187 & 678 & 11.17 & 44.8 \\
\hline 6 & 0.250 & 137.5 & 550 & 1105 & 705 & 11.22 & 44 \\
\hline 7 & 0.249 & 134.46 & 540 & 998 & 780 & 11.35 & 43.2 \\
\hline 8 & 0.248 & 131.44 & 530 & 1050 & 765 & 11.43 & 42.4 \\
\hline 9 & 0.248 & 128.96 & 520 & 980 & 795 & 11.51 & 41.6 \\
\hline 10 & 0.248 & 126.48 & 510 & 1042 & 784 & 11.57 & 40.8 \\
\hline
\end{tabular}

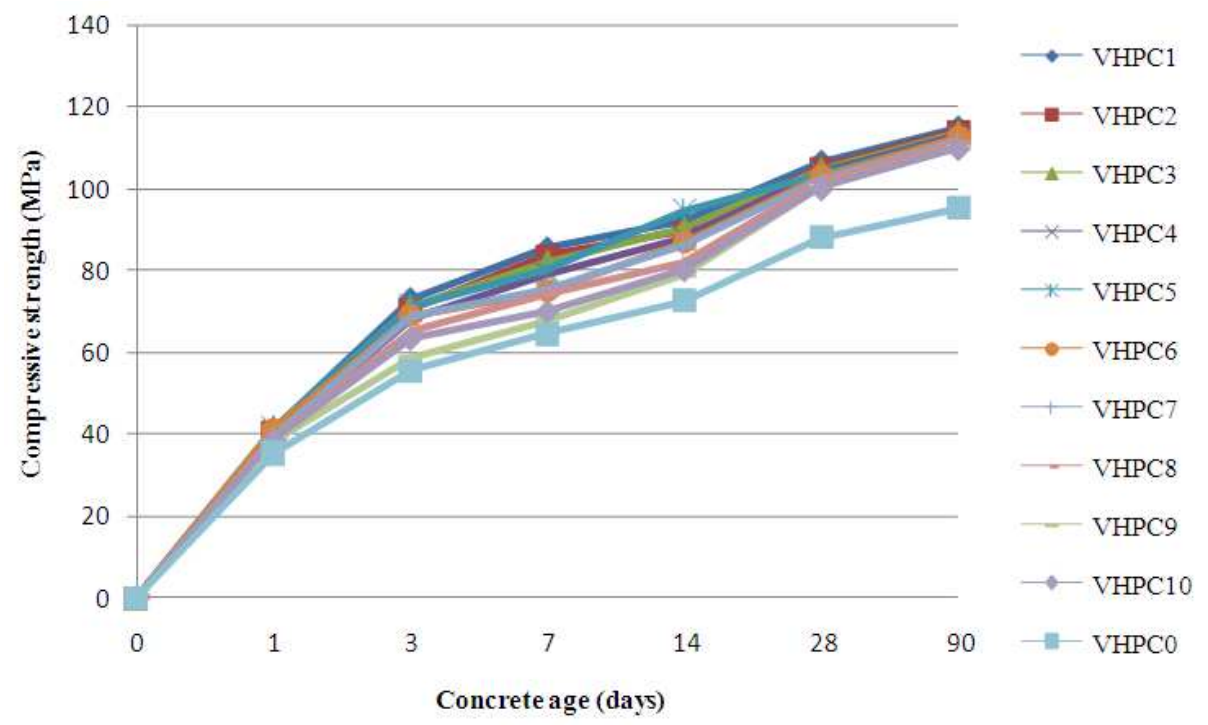

Fig. 2. Compressive strength evolution of different VHPC 


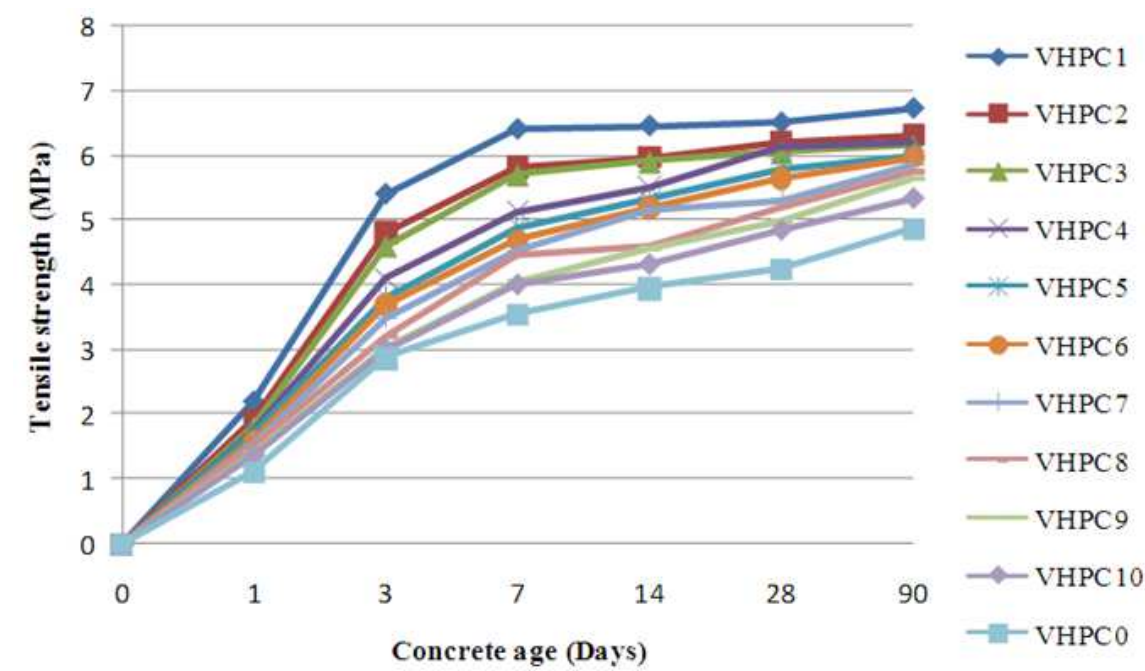

Fig. 3. Tensile strength evolution of different VHPC

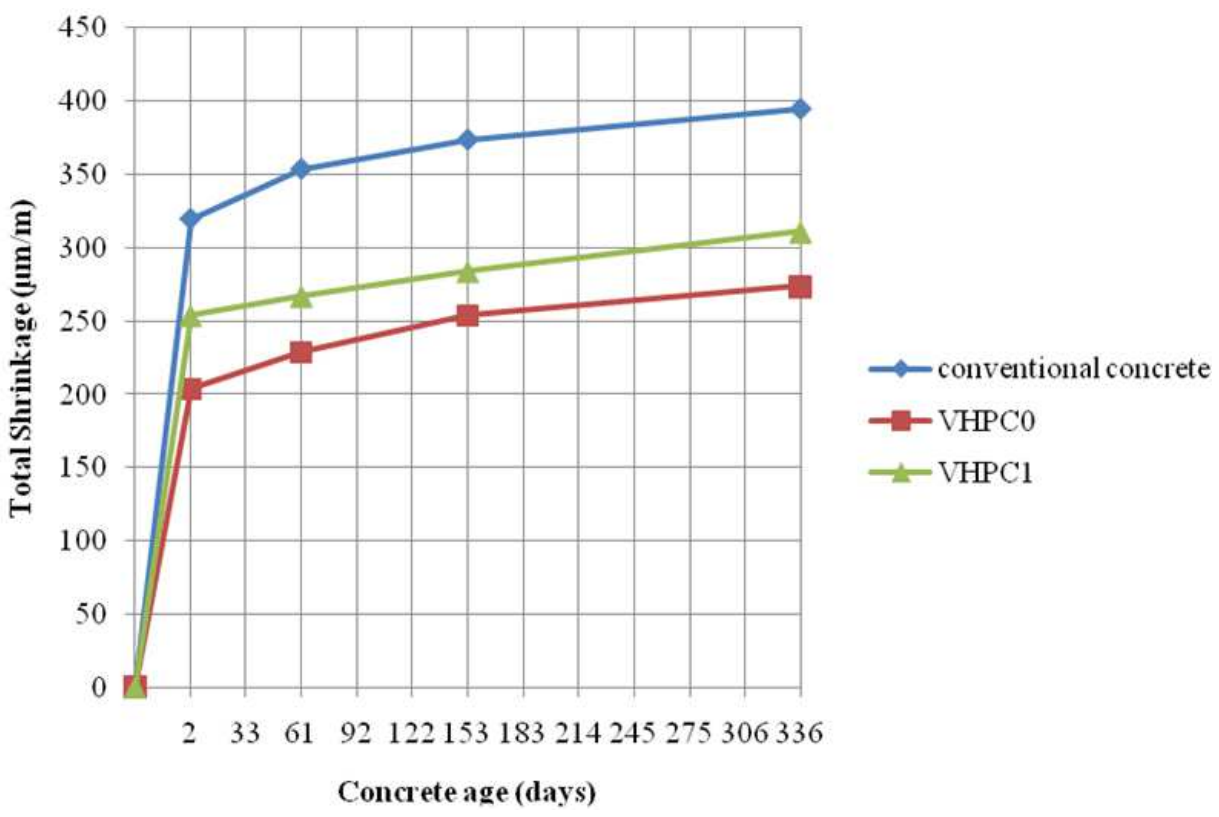

Fig.4. Total shrinkage evolution of different VHPC

\section{Conclusion}

The formulation and production of concrete whose compressive strength at 28 days exceeds $90 \mathrm{MPa}$ is now possible on site in Algeria. The incorporation of silica fumes in concrete showed good strength developments between the ages of 7 and 28 days depending on the composition of mixtures. Concrete with the highest cement content $(600$ $\mathrm{kg} / \mathrm{m}^{3}$ ) presents a higher compressive strength than that of other concrete. The shrinkage properties of VHPC and conventional concrete at early ages are relatively similar in terms of intensity and deformation rates. The total shrinkage testing beyond 24 hours show that VHPC with silica fume leads to a more elevated total shrinkage than those without silica fume, however, he always remains weaker than that in conventional concrete. The VHPC can be used to obtain high compressive and tensile strengths, and an acceptable shrinkage in special structures such as nuclear power plants. The uses of superplasticizers and silica fume as well as the development of new production process have considerably improved the mechanical properties of concrete. Given these results, we could say that the local materials used in this study meet the standards for the production of concrete of quality. Considering the availability of these materials and a good knowledge of the cementitious additions technologies, it is possible to produce in Algeria, sustainable VHPC and it is possible to improve its qualities for most applications.

\section{References}

[1] F. De Larrard and Y. Malier (1989) 'Propriétés constructives des bétons à hautes performances" annales de l'ITBTP $N^{\circ} 479$. 
[2] F. De Larrard, G. Gillet and B. Canitrot, (1996) 'Preliminary HPC mix design study for the Grand Viaduc de Millau: an example of LCPC's approach", in Proceedings of the 4th International Symposium on the Utilization of High-Strength/ High-Performance Concrete, BHP 96, Vol. 3 (eds F.de Larrard and R. Lacroix), Presses de l'ENPC, Paris, ISBN 2-85978-259-1, pp. 1323-32.

[3] B. Lothenbach, F. Winnefeld and R. Figi (2007) "The influence of superplasticizers on the hydration of Portland cement", 12th International Congress on the Chemistry of Cement, Montréal, Canada, July 8-13, 2007.

[4] Y. Malier, (1992); "Les bétons à hautes performances: caractérisation, durabilité, application " : Presse De l'ENPC, Paris, 673p

[5] P. C. Aîtcin (2001) "L'interaction ciment/superplastifiants: cas des polysulfonate" Bulletin des laboratoires des Ponts et Chaussées.

[6] P. K. Chang (2004), "An approach to optimizing mix design for properties of high-performance concrete", Cem. and Conc. Res., vol. 34, Issue 4, April 2004, pp. 623-629.

[7] P. C. Aitcin (1995) "Developments in the application of high-performance concretes", Construction and building materials, Vol. 9, No. 1, pp. 13-17.

[8] A. Ezeldin, and P. C. Aïtcin, (1991) ''Effect of coarse aggregate on the behavior of normal and high-strength concretes". Technical Note in ASTM Journal Cement, Concrete, and Aggregates, 13(2), 121-4.

[9] M. Nehdi, S. Mindess and C. P. Aitcin (1998) 'Rheology of high-performance concrete: effect of ultrafine particles", Cement and Concrete Research, Vol. 28, No. 5, pp. 687-697.

[10] J. Golaszewski and J. Szwabowski, (2004) "Influence of superplasticizers on rheological behaviour of fresh cement mortars", Cem. And Conc. Res., vol. 34, Issue 2, February 2004, pp. 235-248.

[11] D. Chopin (2002), 'Malaxage des bétons à hautes performances et des bétons autoplaçants. Optimisation du temps de fabrication (Mixing of High Performance Concrete and Self Consolidating Concrete-Optimization of mixing time)", PhD thesis of Ecole Centrale de Nantes, January, (in French). Etudes et Recherches des Laboratoires des Ponts et Chaussées, OA 41, 2003, edited by LCPC, 58 bd Lefebvre, 75732 PARIS CEDEX 15.

[12] F. De Larrard, F. Bosc, C. Catherine and F. Deflo renne (1997), "The AFREM method for the mix design of High Performance Concrete", Materials and structures, vol. 30, No. 201, RILEM, Paris, 1997 (August-September), pp. 439-446.

[13] F. De Larrard and T. Sedran (1999), 'Une nouvelle approche de la formulation des Bétons". Annales du bâtiment et des travaux publics, no.6, Décembre 1999, p. 39-54.

[14] P. C. Aïtcin, A. Neville. and P. Acker (1998), 'Les différents types de retrait du béton". Bulletin du LCPC 215, réf. 4184, mai-juin, p. 41-51.

[15] A. Haouas (2007), "Comportement au jeune âge des matériaux cimentaires. Caractérisation et modélisation chimi-hydro-mécanique du retrait". Thèse de Doctorat, ENS de Cachan, 2007. 